\title{
Spatial patterns of iron- and methane-oxidizing bacterial communities in an irregularly flooded, riparian wetland
}

\author{
Juanjuan Wang ${ }^{1+}$, Sascha Krause ${ }^{1}$, Gerard Muyzer ${ }^{2,3+}$, Marion Meima-Franke ${ }^{1}$, Hendrikus J. Laanbroek ${ }^{1,4}$ \\ and Paul L. E. Bodelier ${ }^{1}$ *
}

${ }^{1}$ Department of Microbial Ecology, Netherlands Institute of Ecology, Wageningen, Netherlands

${ }^{2}$ Department of Biotechnology, Delft University of Technology, Delft, Netherlands

${ }^{3}$ Institute for Biodiversity and Ecosystem Dynamics, University of Amsterdam, Amsterdam, Netherlands

${ }^{4}$ Institute of Environmental Biology, Utrecht University, Utrecht, Netherlands

\section{Edited by:}

Svetlana N. Dedysh, Winogradsky Institute of Microbiology, Russian Academy of Sciences, Russia

Reviewed by:

Marc Gregory Dumont,

Max-Planck-Institute for Terrestrial

Microbiology, Germany

Erin Field, Bigelow Laboratory for

Ocean Sciences, USA

${ }^{*}$ Correspondence:

Paul L. E. Bodelier, Department of

Microbial Ecology, Netherlands

Institute of Ecology,

Droevendaalsesteeg 10, NL-6708 PB

Wageningen, Netherlands.

e-mail:p.bodelier@nioo.knaw.nl

\section{${ }^{\dagger}$ Present address:}

Juanjuan Wang, Limnology/Aquatic Geomicrobiology, Institute of Ecology,

Friedrich Schiller University Jena, Jena, Germany;

Gerard Muyzer, Institute for

Biodiversity and Ecosystem

Dynamics, University of Amsterdam,

Amsterdam, Netherlands.
Iron- and methane-cycling are important processes in wetlands with one connected to plant growth and the other to greenhouse gas emission, respectively. In contrast to acidic habitats, there is scarce information on the ecology of microbes oxidizing ferrous iron at circumneutral $\mathrm{pH}$. The latter is mainly due to the lack of isolated representatives and molecular detection techniques. Recently, we developed PCR-DGGE and QPCR assays to detect and enumerate Gallionella-related neutrophilic iron-oxidizers (Ga-FeOB) enabling the assessment of controlling physical as well as biological factors in various ecosystems. In this study, we investigated the spatial distribution of Ga-FeOB in co-occurrence with methane-oxidizing bacteria (MOB) in a riparian wetland. Soil samples were collected at different spatial scales (ranging from meters to centimeters) representing a hydrological gradient. The diversity of Ga-FeOB was assessed using PCR-DGGE and the abundance of both $\mathrm{Ga}-\mathrm{FeOB}$ and MOB by qPCR. Geostatistical methods were applied to visualize the spatial distribution of both groups. Spatial distribution as well as abundance of $\mathrm{Ga}-\mathrm{FeOB}$ and $\mathrm{MOB}$ was clearly correlated to the hydrological gradient as expressed in moisture content of the soil. Ga-FeOB outnumbered the MOB subgroups suggesting their competitiveness or the prevalence of $\mathrm{Fe}^{2+}$ over $\mathrm{CH}_{4}$ oxidation in this floodplain.

Keywords: Gallionella, iron oxidation, methane oxidation, spatial patterns, geostatistics, riparian, wetland

\section{INTRODUCTION}

Wetland ecosystems are sites of intense biogeochemical cycling due to the interactions between the oxic surface and deeper anoxic soil layers making them highly productive ecosystems (Weiss et al., 2003; Gutknecht et al., 2006; Hartman et al., 2008; Burgin et al., 2011). Apart from being a crucial habitat for many animals, plants, and humans, wetlands are also the largest biological source of the greenhouse gas methane (Ringeval et al., 2011). Cycling of nutrients and emission of methane from wetlands is strongly intertwined due to the oxic-anoxic conditions in close proximity (Kogel-Knabner et al., 2010; Burgin et al., 2011) which is especially distinct for iron and methane (Laanbroek, 2010).

Oxic-anoxic interfaces in wetland soils are significantly extended by roots of wetland plants which are known to release oxygen from their roots, a phenomenon called "radial oxygen loss" (ROL; Armstrong, 1964; Bodelier et al., 2006; Laanbroek, 2010). Next to this, oxygen is also introduced into anoxic soils by other physical or biological processes (Doyle and Otte, 1997; Coci et al., 2005; Mermillod-Blondin and Lemoine, 2010) resulting in sharp redox gradients characteristic of wetland soils and sediments.

As one of the most important elements in biogeochemical redox reactions (Fortin and Langley, 2005), iron interacts with other elemental cycles, which in turn affect the growth and activities of plants and microorganisms. Iron oxides are widely distributed in wetland environments and will be reduced rapidly under anoxic conditions by anaerobic iron(III)-reducing bacteria, that couple the oxidation of organic carbon compounds to the reduction of iron $\left(\mathrm{Fe}^{3+}\right)$ to ferrous iron $\left(\mathrm{Fe}^{2+}\right.$; Lovley, 1997; Burgin et al., 2011). Ferrous iron can be oxidized chemically, however, in freshwater wetlands microbial activity accounts for a large part of the production of iron oxides under circumneutral $\mathrm{pH}$ conditions, despite the fact that chemical oxidation under these conditions proceeds much faster. This contradiction triggered studies detecting ironoxidizing bacteria $(\mathrm{FeOB})$ associated with iron oxides in samples from circumneutral environments (Emerson and Moyer, 1997; Weiss et al., 2003; Chan et al., 2009). Actual bacterial mediation of iron oxidation was also confirmed, further pointing to the important role of $\mathrm{FeOB}$ in the formation of iron oxides (Neubauer et al., 2002).

Despite the fact that a number of $\mathrm{FeOB}$ have been isolated and our understanding of the role of these microorganisms in iron oxidation has significantly progressed (Emerson et al., 2010) virtually nothing is known about the environmental factors affecting the diversity and distribution of $\mathrm{FeOB}$ in their natural habitats. 
Sundby et al. (2003) have proposed that seasonal changes of $\mathrm{O}_{2}$ concentration and pore water $\mathrm{Fe}^{2+}$ availability resulting from the growth and death of roots exert a major control on the precipitation of iron oxides. Neubauer et al. (2007) reported significant temporal changes in the iron-oxidizing community in microcosm studies with plants, which suggests that plant biomass and activity play a key role in rhizospheric $\mathrm{Fe}$ (II) oxidation. Changes in the Gallionella-related FeOB community composition have been observed to depend on season and hydrology in a tidal freshwater marsh (Wang et al., 2011), probably connected to the effects these parameter have on oxygen availability.

Next to chemical oxidation, there are quite a few biotic processes that consume oxygen, such as the oxidation of ammonium, methane, and sulfide, which are all products of anaerobic microbial processes. Thermodynamically, Fe(II) oxidation yields more energy than other chemolithotrophic reactions under oxygenlimiting conditions (Thauer et al., 1977), suggesting that sub-oxic conditions may be the niche occupied by FeOB in wetland soils. However, no information is available on the spatial distribution of niches suitable for FeOB as well as the competition for limiting amounts of oxygen between iron-oxidizing bacteria and other oxygen-consuming organisms.

A well characterized group of microbes also thriving at oxicanoxic boundaries are aerobic methane-oxidizing bacteria (MOB), utilizing methane for carbon as well as energy source (Semrau et al., 2010). The aerobic MOB are represented in the phylum of the Proteobacteria and recently also MOB have been identified within the Verrucomicrobia (Op den Camp et al., 2009). Many environmental factors controlling the ecology of MOB have been studied and indentified (Conrad, 2007; Semrau et al., 2010; Bodelier, 2011). The proteobacterial MOB have traditionally been divided into type I and II, based on phylogeny, physiology, and morphology. On the basis of phylogeny, type I has been subdivided in three subtypes Ia, Ib, and Ic (Lüke and Frenzel, 2011). The obligatory aerobic metabolism of most MOB suggest that their environmental distribution and demands are similar to those for FeOB. For type II and Ia MOB different ecological strategies are emerging, type II being slow responders to substrate availability but persistent in the environment, whereas type Ia harbors species that respond and grow fast upon substrate availability (Steenbergh et al., 2010; Bodelier et al., 2012). Considering this, the vast ecological knowledge available about various environmental as well as isolated subtypes of MOB may be extrapolated to possible co-occurring FeOB. Besides using microbial co-occurrence, the distribution of FeOB according to spatial gradients of controlling environmental conditions is another way of obtaining ecological information. Since the soil is a highly heterogeneous environment, soil components, and properties may exhibit high spatial variations (Franklin and Mills, 2003; Baker et al., 2009; Ferreira et al., 2010). In particular, the perceived microbial community structure may depend on the spatial scale of observation, in the range of centimeters to a few hundred meters (Ettema and Wardle, 2002; Philippot et al., 2009b). Sampling of microbial communities in a spatial design followed by geostatistical analyses has rendered important ecological information on the functioning and distribution of ammonia oxidizers (Wessen et al., 2011), denitrifiers (Philippot et al., 2009b), methane oxidizers (Siljanen et al., 2011) as well as total microbial communities (Philippot et al., 2009a) by estimating the distribution in unsampled areas of experimental plots. However so far nothing is known about the spatial distribution of iron-oxidizing bacterial communities.

The aim of this paper is to assess the spatial distribution of the Gallionella-related FeOB (Ga-FeOB) and MOB communities and their interactions in an irregularly flooded riparian wetland. Collecting samples at different spatial scales representing a hydrological gradient allowed investigating the effect of flooding intensity. Special attention is paid to the influence of sampling scale and elevation on the distribution of both $\mathrm{Ga}-\mathrm{FeOB}$ and $\mathrm{MOB}$. Community structure of $\mathrm{Ga}-\mathrm{FeOB}$ were measured by a previously designed nested PCR-DGGE and abundances of both Ga-FeOB and MOB by qPCR. Community was linked to environmental variables. Spatial distribution of bacterial groups was visualized by interpolated spatial maps. We hypothesized that the community structure of iron-oxidizing bacteria changes with sampling scale and elevation, having an effect on the presence of MOB or vice versa.

\section{MATERIALS AND METHODS SITE AND SAMPLING}

Soil samples were collected from the Ewijkse Waard $\left(51^{\circ} 88^{\prime} \mathrm{N}\right.$, $5^{\circ} 73^{\prime} \mathrm{E}$ ), a riparian floodplain along the River Waal (i.e., a tributary of the River Rhine) in the Netherlands, in November 2006. The soil properties have been described previously in detail (Kemnitz et al., 2004; Steenbergh et al., 2010; Bodelier et al., 2012). The sampling site is located on the embankment of a small oxbow lake which is connected to the river on one side but is separated from the river by an outflow barrier, ensuring that the oxbow lake does not become dry completely. This outflow barrier results in slow retreat of water from the sampling plot after flooding, which results in series of different flooding days within the plot; the highest part being flooded up to 2 weeks per year, while the lowest part can be flooded up to 150 days per year (Bodelier et al., 2012). To assess spatial dependence and heterogeneity a nested design was used as described by Franklin and Mills (2003). In total 73 soil cores $(1.8 \mathrm{~cm} \times 5 \mathrm{~cm})$ were collected in a $10 \mathrm{~m} \times 10 \mathrm{~m}$ plot (Figure 1A). The large-scale spatial level of sampling comprised 24 cores arranged evenly distributed along the sides and diagonals of the plot as depicted in Figure 1A. Nested around the intersection of the diagonals of the large plot, 23 samples were taken using the same distribution but now on a $1 \mathrm{~m} \times 1 \mathrm{~m}$ grid (medium scale; Figure 1B). Nested around the same diagonal again 24 samples were obtained in a $20 \mathrm{~cm} \times 20 \mathrm{~cm}$ grid (small scale; Figure 1C). The $10 \mathrm{~m} \times 10 \mathrm{~m}$ plot was situated on a slope on the embankment of the oxbow lake resulting in an elevation difference of $1.1 \mathrm{~m}$ between the lowest and highest point of the plot. The samples taken at the three spatial scales were classified according to their elevation in the following elevation level classes, low $(0-0.33 \mathrm{~m})$, intermediate $(0.34-0.66 \mathrm{~m})$, and high (0.67-1.1 m). Soil water content (based on dry weight), soil density, total soil organic matter, and water filled pore space were analyzed using standard methods.

\section{DNA EXTRACTION}

DNA was extracted using a modification of the method described Yeates and Gillings (1998), based on the FastDNA spin kit for soil (MP Biomedicals, LLC, Solon, OH, USA), as described earlier (Pan et al., 2010). Soil (0.3 g) and $780 \mu l$ lysis buffer [200 $\mathrm{mM} \mathrm{NaPO}_{4}$ 


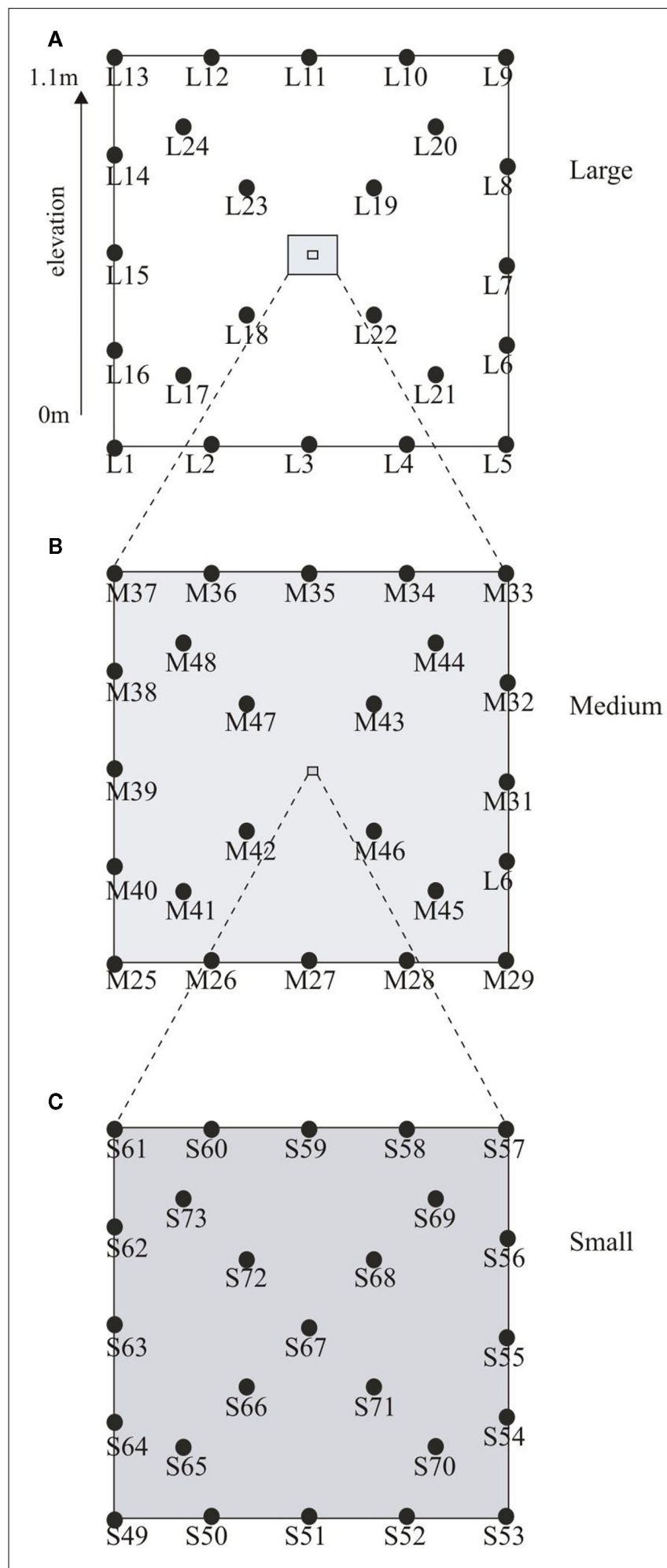

FIGURE 1 | Graphical representation of the sampling scheme. Depicted in $(\mathbf{A})$ is the large-scale plot $(10 \mathrm{~m} \times 10 \mathrm{~m})$ with an elevation from 0 to $1.1 \mathrm{~m}$. Samples were taken at $2.5 \mathrm{~m}$ intervals along the sides and $2.35 \mathrm{~m}$ intervals along the diagonals. (B) Shows the medium plot $(1 \mathrm{~m} \times 1 \mathrm{~m})$ with sampling interval of $25 \mathrm{~cm}$ along the sides and $23.5 \mathrm{~cm}$ along the diagonals while (C) depicts the small plot $(20 \mathrm{~cm} \times 20 \mathrm{~cm}$ ) with samples intervals of $5.0 \mathrm{~cm}$ along the sides and $4.7 \mathrm{~cm}$ along the diagonals.
pH 7.0; 1\% (w/v) CTAB; $1.5 \mathrm{M} \mathrm{NaCl} ; 2 \%$ (w/v) Polyvinylpyrrolidone $\mathrm{K} 30 ; 5 \mathrm{mg} \mathrm{ml}^{-1}$ lysozyme (added directly before use)] was added into a multimix FastPrep tube and incubated at $37^{\circ} \mathrm{C}$ for $30 \mathrm{~min}$. MT buffer $(122 \mu \mathrm{l})$, provided with the kit, was added and tubes were shaken in the FastPrep instrument (MP, Biomedicals, LLC, Solon, OH, USA) for $30 \mathrm{~s}$ at $5.5 \mathrm{~m} \mathrm{~s}^{-1}$. Subsequently, samples were centrifuged for $15 \mathrm{~min}$ at $10000 \mathrm{rpm}$ and $700 \mu \mathrm{l}$ supernatant was collected. The pellet was re-extracted by adding lysis buffer $(500 \mu \mathrm{l})$ and $50 \mu \mathrm{l}$ MT buffer to the FastPrep tubes, shaken in the FastPrep instrument for $30 \mathrm{~s}$ at $5.5 \mathrm{~m} \mathrm{~s}^{-1}$ again followed by the transfer of the second $700 \mu l$ of supernatant into separate Eppendorf tubes. At this step, $2 \mu l \times 700 \mu l$ supernatant was obtained from each sample. Five microliters of $10 \mathrm{mg} \mathrm{ml}^{-1}$ freshly made proteinase $\mathrm{K}$ was added to each tube. Tubes were incubated at $65^{\circ} \mathrm{C}$ for $30 \mathrm{~min}$. Samples were extracted with phenol-chloroformisoamyl alcohol (25:24:1), followed by a chloroform-isoamyl alcohol (24:1) extraction. One hundred twenty-five microliters of $7.5 \mathrm{M}$ potassium acetate was added, samples were incubated on ice for $5 \mathrm{~min}$, and then centrifuged at $10000 \mathrm{rpm}$ for $10 \mathrm{~min}$. Supernatants $(2 \times 700 \mu \mathrm{l}$ per soil sample $)$ were transferred to new tubes, $700 \mu l$ Binding Matrix was added, and tubes were mixed for $5 \mathrm{~min}$ on a rotator. Binding Matrix, with bound DNA, was pelleted by 1 min centrifugation at $10000 \mathrm{rpm}$. The supernatant was discarded and pellet was resuspended in $500 \mu \mathrm{l}$ wash buffer. The resulting suspension was added into a Spin filter, and centrifuged for $1 \mathrm{~min}$ at $10000 \mathrm{rpm}$. The eluent was discarded and the pellet was washed again in $500 \mu \mathrm{l}$ wash buffer. After discarding the second eluent, the Spinfilter was centrifuged for another $10 \mathrm{~s}$ to dry the pellet. The filter was taken into a new tube and $50 \mu 1$ of TE $\mathrm{pH} 8.0$ was added. The filter was incubated at room temperature for $1 \mathrm{~min}$ and centrifuged for $1 \mathrm{~min}$. The filter was re-eluted in the same way with $50 \mu \mathrm{l}$ of TE $\mathrm{pH}$ 8.0. The eluent collected in the catch tube contained the purified DNA. A total of 18 out of 73 samples (i.e., L1-5, M25, M31, M 46, M 49, S50, S52, S53, S56, S60, S63, S65, $\mathrm{S} 67$, and S72) did not give products during PCR procedures and were excluded from further analysis.

\section{PCR-DGGE}

A nested PCR-DGGE targeting Ga-FeOB was performed using a previously developed assay (Wang et al., 2009). Briefly, $1 \mu$ of $50 \mathrm{ng}^{-1}$ purified environmental DNA was used for the first step PCR with primer set $122 \mathrm{~F}-998 \mathrm{R}$. The PCR was run in a $50-\mu \mathrm{l}$ reaction volume containing $5 \mu \mathrm{M}$ of each primer, $2.5 \mathrm{mM}$ of dNTPs, $1.5 \mathrm{mM} \mathrm{MgCl}_{2}, 2 \mathrm{mM} \mathrm{BSA}$, and 1.25 units Taq DNA polymerase. The PCR conditions included 1 cycle of $5 \mathrm{~min}$ at $94^{\circ} \mathrm{C}$, followed by 30 cycles of $1 \mathrm{~min}$ at $94^{\circ} \mathrm{C}, 1 \mathrm{~min}$ at $55^{\circ} \mathrm{C}$, and $1.5 \mathrm{~min}$ at $72^{\circ} \mathrm{C}$, the final extension cycle was $10 \mathrm{~min}$ at $72^{\circ} \mathrm{C}$. The PCR products were diluted 10 times and $2 \mu \mathrm{l}$ of the dilution was used for a second-step PCR using universal primers set GC-F357 and 907R following a touch-down PCR cycle (Schäfer et al., 2001). Clones generated in a previous study (Wang et al., 2009), representing different phylogenetic taxa, were re-amplified using general bacterial DGGE primers GC-F357 and R907 (Muyzer et al., 1993), and used as markers. DGGE was performed with the Bio-Rad Protean II system as described previously (Muyzer et al., 1993). An $8 \%$ polyacrylamide gel with a vertical gradient of $30-60 \%$ of the denaturant was used to analyze the $550 \mathrm{bp}$ PCR products. 
Equal volumes of the PCR products obtained after the second PCR reaction were loaded. The running conditions was $100 \mathrm{~V}$ at a constant temperature of $60^{\circ} \mathrm{C}$ in $23 \mathrm{~L}$ of $0.5 \times$ TAE buffer (20 mM Tris acetate, $0.5 \mathrm{mM}$ EDTA, $\mathrm{pH} 8.0$ ) for $18 \mathrm{~h}$. The DGGE gels were visualized using an UV transilluminator after ethidium bromide-staining. The representative bands were excised, purified, and sequenced. The sequences were checked and manually modified using Sequencher software (Gene Codes Corporation, City, USA) and aligned in the ARB program (Ludwig et al., 2004). A phylogenetic tree was constructed using the Neighbor Joining method. Sequences were deposited with GenBank under the following accession numbers JQ060106-JQ060114, representing DGGE bands G14-G37, respectively.

\section{REAL-TIME PCR}

A recently developed real-time PCR assay (Wang et al., 2011) was used to quantify the Ga-FeOB bacteria in the samples collected. The primer set includes a degenerate forward primer 628F (GBMAGGCTAGAGTGTAGC) and a reverse primer 998R (CTCTGGAAACTTCCTGAC). DNA from soil samples was puri-

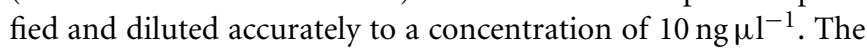
real-time PCR was performed in a $25-\mu 1$ reaction volume containing $2.5 \mu$ l purified DNA and $22.5 \mu$ SYBR $^{\circledR}$ Green PCR Master Mix (Invitrogen). The concentration of each primer was $5 \mathrm{pmol}_{\mu \mathrm{l}^{-1}}$. The PCR involved 45 cycles, with each cycle consisting of denaturation at $95^{\circ} \mathrm{C}$ for $20 \mathrm{~s}$, annealing at $56^{\circ} \mathrm{C}$ for $20 \mathrm{~s}$, and extension at $72^{\circ} \mathrm{C}$ for $45 \mathrm{~s}$. Data acquisition was done at $82^{\circ} \mathrm{C}$ for $10 \mathrm{~s}$, to avoid signal from primer dimer formation. The DNA copy number of $\mathrm{Ga}-\mathrm{FeOB}$ in each sample was estimated by comparing the $\mathrm{C}_{t}$ value of each sample to those of the standard regression line, which was made by using reference clones (Wang et al., 2009, 2011). Three methanotrophic subgroups were quantified by pmoA-based quantitative PCR based on the assays described by Kolb et al. (2003). The type Ia, Ib, and II assays were carried out as previously described (Pan et al., 2010) with $25 \mu \mathrm{l}$ reaction containing $12.5 \mu \mathrm{l} 2 \times$ SYBR green mix (AB gene, Epsom, UK), $2.5 \mu$ l of diluted DNA template and $0.8 \mathrm{mM}$ each of primers. The samples were diluted accurately to $1 \mathrm{ng} \mu \mathrm{l}^{-1}$. The thermal cycle started with an initial denaturation at $95^{\circ} \mathrm{C}$ for $15 \mathrm{~min}$, followed by 45 cycles of denaturation at $95^{\circ} \mathrm{C}$ for $20 \mathrm{~s}$, annealing at $64^{\circ} \mathrm{C}$ for $20 \mathrm{~s}$, and extension at $72^{\circ} \mathrm{C}$ for $45 \mathrm{~s}$. Fluorescence was recorded at $84^{\circ} \mathrm{C}$ and DNA melting curve analysis was performed at temperatures ranging from 70 to $99^{\circ} \mathrm{C}$. All assays (Ga-FeOB and $\mathrm{MOB}$ ) were performed with a RotorGene 6000 thermal cycling system (Corbett Research, Eight Mile Plains, QLD, Australia), where samples were added to aliquots of the master mixture using a CAS-1200 (Corbett Robotics Eight Mile Plains, QLD, Australia) liquid handling system. Every sample was performed in duplicate. Quantification analysis was performed by the Rotor-Gene software. A number of samples failed to reach the detection limit of the assays: Ga-FeOB (M25, M27, M31, M37, M48, S49-S59, S63, S64, S65, S67). Type Ia MOB (L2, S50, S52, S54-S59, S60, S61, S64, S65). Type Ib MOB (S52). Type II MOB (M45).

\section{DATA ANALYSIS}

DGGE gels were analyzed using Phoretix gel analysis software (Phoretix International, Newcastle upon Tyne, UK). The number of bands of each lane was defined and a matrix of band intensity was created. Lanes were created manually, with a fixed width of 5\% of the standard lane width. Each lane represents one sample. Background noise was subtracted by using the Rolling Ball algorithm with a radius of 50 pixels. Bands were detected automatically with a minimum slope of 100 and a noise reduction of 4 . Then bands were assessed and corrected by eye, matched to a reference lane (Markers), and quantified. The relative abundance of each band was defined as the intensity ratio of each band to the total intensity of individual lanes.

Similarity between DGGE community profiles was analyzed using multivariate analyses in PRIMER 5 software (Plymouth Marine Laboratory, Plymouth, UK). Relative abundance data derived from the DGGE gels were used in non-metric Multidimensional Scaling (MDS) analyses. The input of MDS analyses were Bray-Curtis similarity matrices generated using log $(x+1)$ transformed relative abundances data. The MDS analyses results in a two-dimensional plot where the distance between samples indicates the similarity of these samples relative to other samples in the plot. The accuracy of the two-dimensional representation is indicated by the "Stress" value (Kruskal's stress formula). Stress values $<0.1$ indicate a good ordination with no prospect of misleading interpretation. Stress values $<0.2$ still give a good two-dimensional representation where not too much reliance should be put on the detail. Theoretical aspects of the MDS analyses used are described by Clarke and Warwick (2001). One-way ANOSIM in PRIMER software test was used to compare samples between different scales (Clarke and Warwick, 1998). Data of the relative abundance of each band was log-transformed and analyzed using Statistica software package (Statistica version 9, StatSoft, Inc., Tulsa, USA), together with the qPCR results, and a number of defined environmental parameters. The distribution of bacterial abundance at different elevation levels and sampling scales was compared using ANOVA. Post hoc Tukey analysis was used to further compare the difference among samples. The relation between $\mathrm{Ga}-\mathrm{FeOB}$ and MOB was done using non-parametric pair wise correlation in Statistica.

To model the spatial structures of the total abundance of GaFeOB (logarithm of the total 16s rRNA gene copy number), MOB (logarithm of the total $p m o A$ gene copy number), and the moisture content (weight percentages) geostatistics were applied. These methods originate from mineralogy and soil science and are a common tool to identify and model spatial patterns (Legendre and Legendre, 1998). The basic principle is autocorrelation of spatial variability, i.e., close-set samples are more similar than those further apart (Ettema and Wardle, 2002). In a first step a variogram analysis was performed. In brief, semi-variances between samples were calculated and plotted against their spatial separation; the slope indicated whether a spatial structure is present or not (Ettema and Wardle, 2002). The Hawkins and Cressie's modulus estimator was calculated to create variograms and maximum likelihood (ML) estimations with Matérn covariance function was fitted to semi-variance values (Cressie, 1993). The estimated model parameters have been used for kriging. This is a geostatistical method to visualize spatial structures of properties by spatial interpolation maps (Ribeiro and Diggle, 2001). Before kriging, goodness of fit of the model parameters has been tested by cross validation. To 


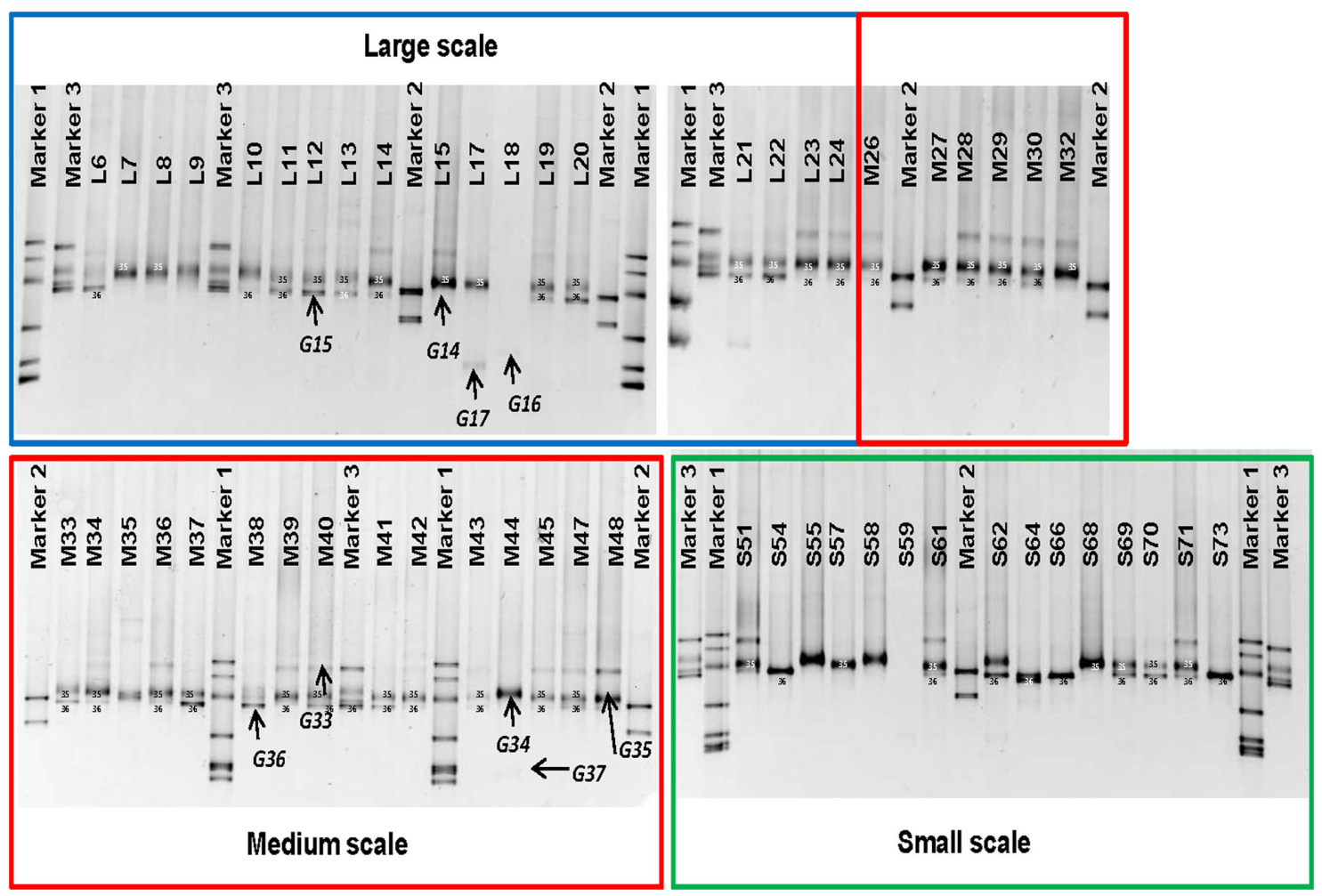

FIGURE 2 | DGGE patterns showing the distribution of iron-oxidizing bacteria at different sampling scales, which are indicated by colored boxes. Bands G14-G17 and G33-G37 were sequenced and shown in

Figure 4. Sequenced clones obtained previously were used as markers.
Marker1: MWE_C40(FJ391490), MWE_N41(FJ391496), MWE_N34(FJ391502), MWE_N13(FJ391501), MWE_N19(FJ391497), and MWE_N26(FJ391498), Marker2: Hc1(FJ391520), and Hc25(FJ391510), Marker3: Hc9(FJ391509), Hc37(FJ391515), Hc16 (FJ391516), and Hc8(FJ391513; Wang et al., 2009). create spatial interpolation maps of moisture content, Ga-FeOB, and MOB abundances we used ordinary kriging applying global neighborhood. All geostatistical analyses were performed using the geostatistical data analysis software geoR as implemented in the statistical software R (Ribeiro and Diggle, 2001; R Development Core Team, 2010).

\section{RESULTS}

\section{COMMUNITY STRUCTURE OF GALLIONELLA-RELATED FeOB}

Between one and four bands in each sample were retrieved from the DGGE gels (Figure 2). There is a trend toward fewer bands in the samples collected at the small scale. Taking the relative intensities of the bands as input matrix for multivariate analyses using multidimensional scaling showed that the Ga-FeOB community in samples taken from large and medium scales differed from the samples collected at small scale, but not from each other (Figure 3; ANOSIM analyses, $R=0.42$, large vs small, $R=0.43$ medium vs small). A total of nine bands were retrieved from the DGGE gels and sequenced. They were distantly related to known cultures, with uncultured clones as most close relatives (Figure 4). The most dominant band (G35, G14, Figure 2) from the medium-scale and large-scale samples was closely related to a recently isolated neutrophilic Ga-FeOB strain HDD (Wang, 2011). The most closely isolated relative to Band G37, G16, and G17 is Sideroxydans lithotrophicus strain LD-1 (Weiss et al., 2007), a microaerophilic iron-oxidizing bacterium. Bands G33 and G34 were most closely related to uncultured Gallionella-related clones Hc9 and Hc16, respectively (Figure 4) isolated from a freshwater wetland (Wang et al., 2009). G15 and G 36 are most closely related to Gallionella-related clones (Hc8) obtained from the same wetland (Wang et al., 2009).

\section{EFFECTS OF SPATIAL SCALE AND ELEVATION LEVEL ON THE ABUNDANCE AND DIVERSITY OF GALLIONELLA-RELATED FeOB AND MOB Spatial scale}

The abundance of Gallionella-related FeOB as determined by copy numbers of $16 \mathrm{~s}$ rRNA genes, ranged from $1 \times 10^{3}$ to $3.9 \times 10^{8}$ per gram dry soil. Five out of 23 medium-scale samples did not yield product in the qPCR analyses, indicating that their $16 \mathrm{~s}$ rRNA copy numbers were below the detection limit, and thus were excluded from the analyses. The highest copy number was observed in sample L20, taken in the high elevation part. The average copy numbers of the 16s rRNA gene from samples taken at large and medium scales, i.e., $4.6 \times 10^{7}$ and $3.7 \times 10^{7}$ copies per gram dry weight, respectively, were significantly higher than that of the small-scale samples $\left(5.4 \times 10^{6}\right.$ copies per gram dry weight; Figure 5A).

One-way ANOVA test indicated significant differences of Gallionella-related iron-oxidizing bacteria as well as methane oxidizers across spatial scales (Table 1). Post hoc Tukey test indicated that the abundance of both Ga-FeOB and MOB in samples 
taken at small scale was significantly lower than those at largeand medium-scale plots $(p<0.05)$. No difference was observed between large- and medium-scale samples.

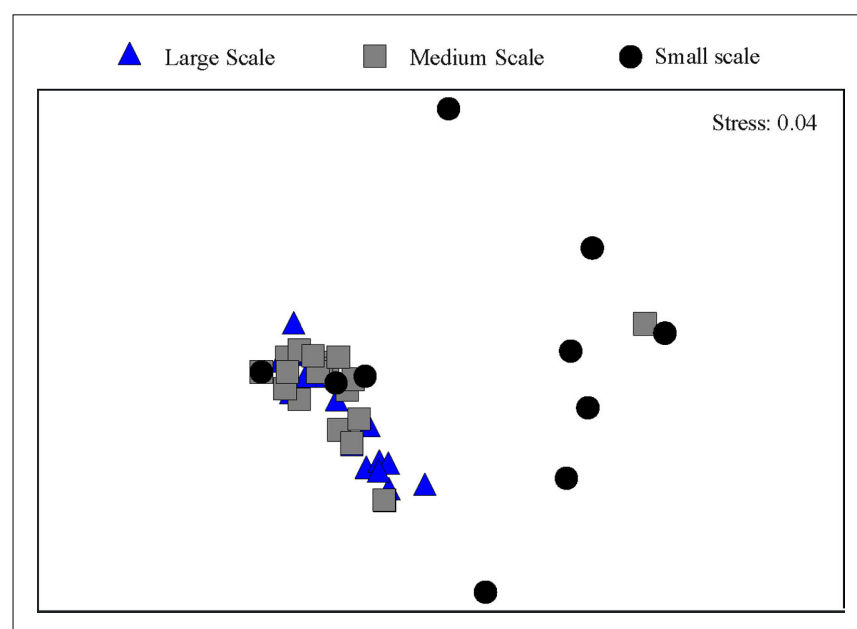

FIGURE 3 | Ordination by non-metric multidimensional scaling of log $(x+1)$ transformed relative abundance of the DGGE bands of the samples taken at different spatial scales.
At large- and medium-sampling scales, the total gene copy numbers of the different bacterial groups followed the sequence, $\mathrm{Ga}-\mathrm{FeOB}>\mathrm{MOB}$ type $\mathrm{II}>$ type $1 \mathrm{~b}>$ type Ia (Figure 5A). Significant differences were detected between all the groups except for type II and type Ib MOB. In the small-scale sampling plot, the abundance of MOB type Ia was significantly lower than in the rest of the samples (Figure 5A).

A diverse pattern of relative abundance of the bands retrieved from the DGGE gels was obtained. Among all the bands detected, band G35 and band G36 were the most abundant ones (Figure 2) off which G35 showed a similar trend to the average abundance detected using qPCR (Figure 6A). The relative abundance of band G35 dropped significantly at small-sampling scale as compared to large- and medium-scale samples whereas G36 did not. The rest of the bands did not show a clear trend given spatial level as a factor.

\section{Elevation level}

ANOVA analyses demonstrated that elevation significantly affected the numbers of FeOB and type I a MOB (Table 1). With the increase of elevation, the abundance of FeOB increased significantly (Figure 5B). Again in this case, the relative abundance of band G35 followed the same positive trend with increasing elevation which was not the case for G36 (Figure 6B). MOB showed a similar trend as the Ga-FeOB except for type Ia, which

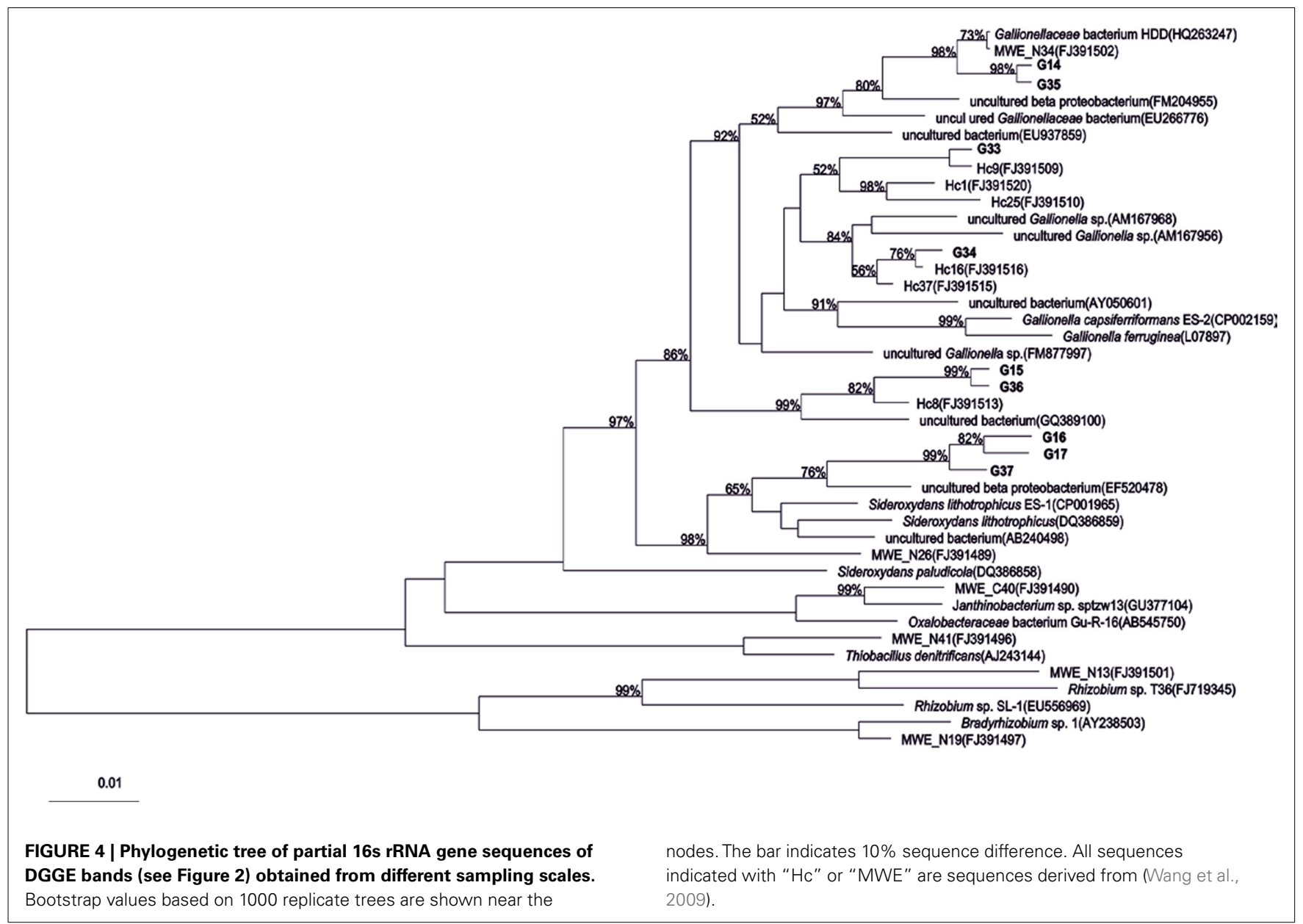




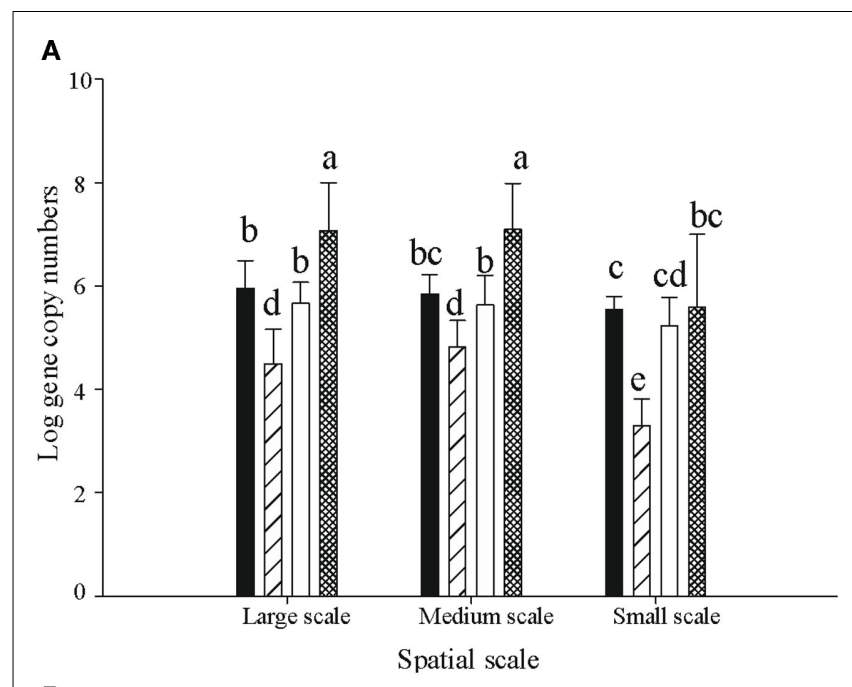

B

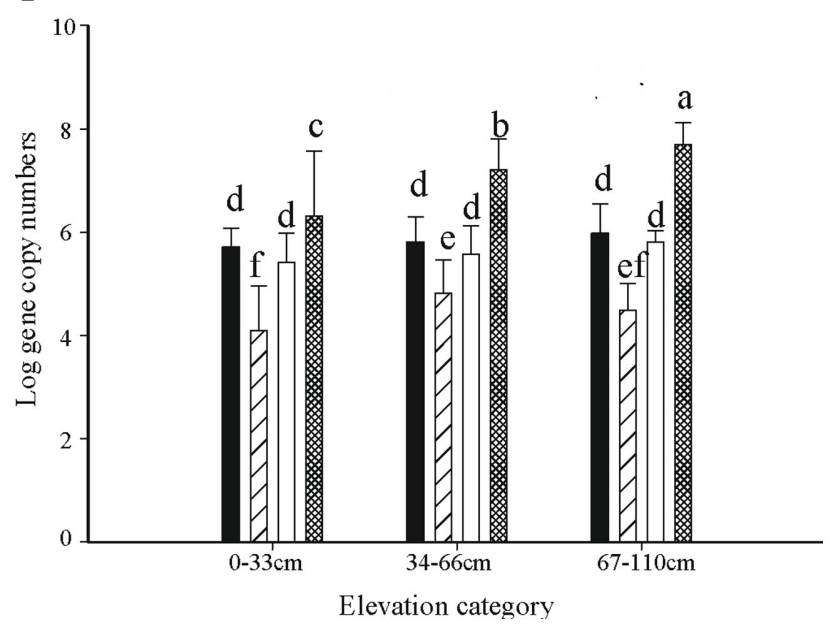

FIGURE 5 |The distribution of 16s rRNA copy numbers of Ga-FeOB and pmoA gene copy numbers of $M O B$ (both expressed per gram of dry soil) at different spatial scales (A) and elevation levels (B). Indicated are means \pm SD. Black bars depict type II, striped bars type la, and white bars type Ib MOB, while hatched bars show the Ga-FeOB. Different letters indicate significant differences $(p<0.01)$ between bars. For numbers of observations see footnote of Table 1

displayed maximum abundance in the intermediate elevation level (Figure 5B). There was a significant difference between the abundance of type Ia in samples taken from medium $(33-46 \mathrm{~cm})$ and low level $(0-33 \mathrm{~cm})$. No difference was observed among the abundance of other types of methane oxidizers along the elevation gradient.

The total 16s rRNA gene copy numbers detected for Ga-FeOB was much higher (10- to 100-fold) than the pmoA gene numbers of the different types of methane oxidizers at all elevation levels. The only reported 16s RNA copy numbers for iron-oxidizing genomes reported indicate two copies per genome (Fleming et al., 2011) while MOB generally have two to three copies of the $p m o A$ gene (Kolb et al., 2003) supporting the absolute dominance of Ga$\mathrm{FeOB}$ over MOB in terms of cell numbers. Overall, abundance of $\mathrm{Ga}-\mathrm{FeOB}$ and $\mathrm{MOB}$ of all three sub-types were positively correlated (Table 2).

\section{Spatial interpolation maps}

Interpolated maps revealed that $\mathrm{Ga}-\mathrm{FeOB}$ and $\mathrm{MOB}$ abundances display different spatial patterns (Figures 7B-E). While a gradient was observed in $\mathrm{Ga}-\mathrm{FeOB}$ and type I MOB abundances, type II MOB did not follow a gradient. A comparison between interpolated maps of soil moisture content and $\mathrm{Ga}-\mathrm{FeOB}$ abundance data indicated a negative correlation between these two factors (Figures 7A,B). This was confirmed by Spearman correlation analyses using only the measured data (Table 2). Similarly, type I MOB abundances (Figures 7A,C,D) indicated a negative correlation with moisture content which was supported by Spearman correlation (Table 2). Ga-FeOB and type Ib showed also the highest spatial dependencies (Table 3). Type Ib displayed a very similar distribution as $\mathrm{Ga}-\mathrm{FeOB}$ while type Ia abundance tends to be highest at intermediate elevations levels of the study site. Type II showed a distinctly deviating distribution (Figure 7E) which did also not correlate with moisture content (Table 2). Interestingly the lowest moisture content was observed not at the top of sampling plot, but to the side of the plot with the highest plant biomass (i.e., $0.56-1.12 \mathrm{~m}$ higher than the lowest point of the plot).

\section{DISCUSSION}

The present study gives insights into the spatial patterns of microbes involved in two important geochemical processes along a hydrological gradient. Ga-FeOB outnumber $\mathrm{MOB}$ but their abundance is positively correlated to various subgroups of $\mathrm{MOB}$, indicating that there are shared controlling environmental factors.

The strong increase in numbers of iron-oxidizing bacteria with elevation and the negative correlation with soil moisture content indicate that the hydrological gradient is one of the important environmental factors that control the distribution of the $\mathrm{Ga}$ $\mathrm{FeOB}$. However, the distribution of $\mathrm{Ga}-\mathrm{FeOB}$ in the present study was opposite to the distribution of $\mathrm{Ga}-\mathrm{FeOB}$ in a tidal freshwater marsh showing higher numbers in the regularly flooded, lower parts of the marsh compared to the higher parts (Wang et al., 2011). The strong relationship with Fe(III) availability and Ga$\mathrm{FeOB}$ abundance in the study of Wang et al. (2011) pointed to iron as the primary controlling factor, a fact recently also observed in drinking water distribution systems (Li et al., 2010). Although we did not measure iron availability at time of sampling in the present study, an earlier study at the same site showed that total Fe in these soils is around $5 \mathrm{ppm}$ (Conrad et al., 2008). This observation combined with the orders of magnitude higher numbers of $\mathrm{Ga}-\mathrm{FeOB}$ found as compared to the tidal freshwater marsh, indicates that iron availability was not limiting at the floodplain site. As soil moisture content decreases with elevation (Figure 7A), the availability, and penetration depth of oxygen into the soil likely increases also, which in itself should favor bacterial iron oxidation. However, when soil oxygenation increases, more ferrous iron may be consumed by chemical iron oxidation. A decrease in soil moisture content may also lead to less iron reduction, which consequently slows down the redox turnover of iron (Blothe and Roden, 2009). Together, this would lead to low ferrous iron supply, a key factor for iron-oxidizing activity. Apparently, the conditions also 
Table 1 | ANOVA analyses of effects of spatial factors and elevation on gene copy numbers of Ga-FeOB, type la, lb, and II MOB.

\begin{tabular}{|c|c|c|c|c|c|}
\hline Factor & ss & DF & MS & $F$ & $p$ \\
\hline \multicolumn{6}{|l|}{ SPATIAL } \\
\hline $\mathrm{Ga}-\mathrm{FeOB}$ & 2.197 & 2 & 1.098 & 6.82 & 0.0019 \\
\hline Type la & 2.617 & 2 & 1.308 & 4.941 & 0.0099 \\
\hline Type Ib & 15.045 & 2 & 7.522 & 7.550 & 0.0014 \\
\hline Type II & 0.615 & 2 & 0.307 & 1.670 & 0.1957 \\
\hline Type la & 5.9770 & 2 & 2.9885 & 5.152 & 0.0087 \\
\hline Type Ib & 1.361 & 2 & 0.680 & 2.400 & 0.0984 \\
\hline
\end{tabular}

$p$ Values in bold indicate statistically significant ( $p<0.05)$ ANOVA F values and hence, significant effects of the variables on gene copy numbers. SS, sum of squares; DF, degrees of freedom; MS, mean square; F, ANOVA F statistic.

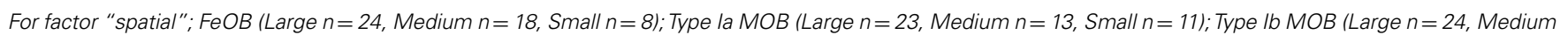

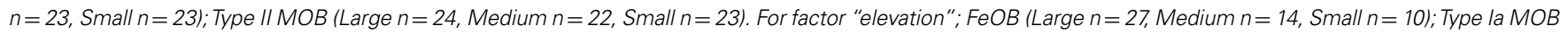
(Large $n=33$, Medium $n=17$, Small $n=10) ;$ Type Ib MOB (Large $n=40$, Medium $n=20$, Small $n=10) ;$ Type $/ /$ MOB $($ Large $n=42, M e d i u m n=20$, Small $n=10)$.

in the upper parts of the floodplain are such that oxygen and ferrous iron are both available and that $\mathrm{Ga}-\mathrm{FeOB}$ can compete with chemical oxidation.

All Ga-FeOB so far isolated are all lithotrophic obligatory aerobic bacteria which mainly are controlled by the availability of $\mathrm{Fe}_{2}^{+}$and $\mathrm{O}_{2}$ (Emerson et al., 2010). The dominant Ga-FeOB in this study (represented by band G35 and G36) display a clearly different distribution. G35 increases with elevation related to the lower water content and probably to the connected oxygen availability. The sequence is closely related to an isolate also derived from an irregular flooded riparian soil and tentatively called "Ferricurvibacter nieuwersluisensis"(Wang, 2011) which also grew in gradient tubes under microaerophilic conditions but also could tolerate exposure to higher amounts of oxygen (Wang, 2011). G36 did not display an elevation-related distribution in this irregular floodplain but is highly related to a sequence (Hc8 in Figure 2) which was the most dominant one in a tidal marsh, where it also correlated positively with iron availability (Wang, 2011). Although, we have no physiological data to support any firm conclusions regarding environmental control, it seems that within the GaFeOB there is habitat preference and niche differentiation likely related to the local regimes of $\mathrm{O}_{2}$ and or $\mathrm{Fe}_{2}^{+}$availability. Considering the limited number of isolates and lack of physiological knowledge of these isolates, it would be too speculative to discuss other environmental controls. However, considering the phylogenetic diversity in the proposed order Gallionellales (Emerson et al., 2010; Figure 4) it can be expected that behind the sequences there will be microbes with a broader metabolic repertoire and different oxygen tolerances than isolated so far, offering explanations for the environmental patterns observed in various environments.

The irregular flooded riparian floodplain studied and the tidal marsh investigated in a previous study (Wang et al., 2011) were very similar in terms of $\mathrm{Ga}-\mathrm{FeOB}$ community composition but differed markedly in Ga-FeOB abundance Although the primers are targeting Gallionella-related FeOB only, the range of different sequence types or strains potentially detected by the primers used is much higher than detected in both studies (Wang et al., 2009) rendering it unlikely that the resemblance is due to a primer bias. This leads to the conclusion that physico-chemical conditions at the irregularly flooded site are better for performance of the dominant Ga-FeOB at that site. The alternative explanation would be that competition with other microbes and processes is more intense in the tidal freshwater marsh.

According to thermodynamics (Thauer et al., 1977; Sobolev and Roden, 2002), the oxidation processes should follow the order of ferrous iron $>$ methane $>$ sulfide $>$ ammonium oxidation under conditions of oxygen limitation. It has been suggested by Neubauer et al. (2002) that neutrophilic Fe(II)-oxidizing bacteria may compete for limiting amounts of $\mathrm{O}_{2}$ in the rhizosphere and therefore influence other wetland biogeochemical cycles. van Bodegom et al. (2001b) also reported that iron oxidation was the most important oxidative process in a rice paddy rhizosphere and accounted initially for $97 \%$ of the consumed oxygen using a detailed mechanistic model (van Bodegom et al., 2001a). However, in an accompanying study these authors did not detect iron oxidizers by means of traditional cultivation-dependent most probable number counts and concluded that this oxidation was mainly chemical and that microbial iron oxidation was negligible (van Bodegom et al., 2001b). However, in our irregularly flooded site the Ga-FeOB outnumber the various groups of MOB yielding the first experimental evidence suggesting that on microbial population level microbial iron oxidation can prevail over methane consumption and that chemical iron oxidation may not be as dominant as assumed. We have to bear in mind though that this conclusion is based on DNA-based abundance assessment and not on measured processes.

The recent isolation and genomic description of a marine neutrophilic iron oxidizer provided evidence for the microaerophilic nature and high affinity for oxygen of $\mathrm{FeOB}$, which would enable them to be active at lower oxygen concentrations than chemical oxidation and methane oxidizers can (Singer et al., 2011). However, there are no clues to the extent to which this information can be extrapolated to freshwater wetlands. The recent 

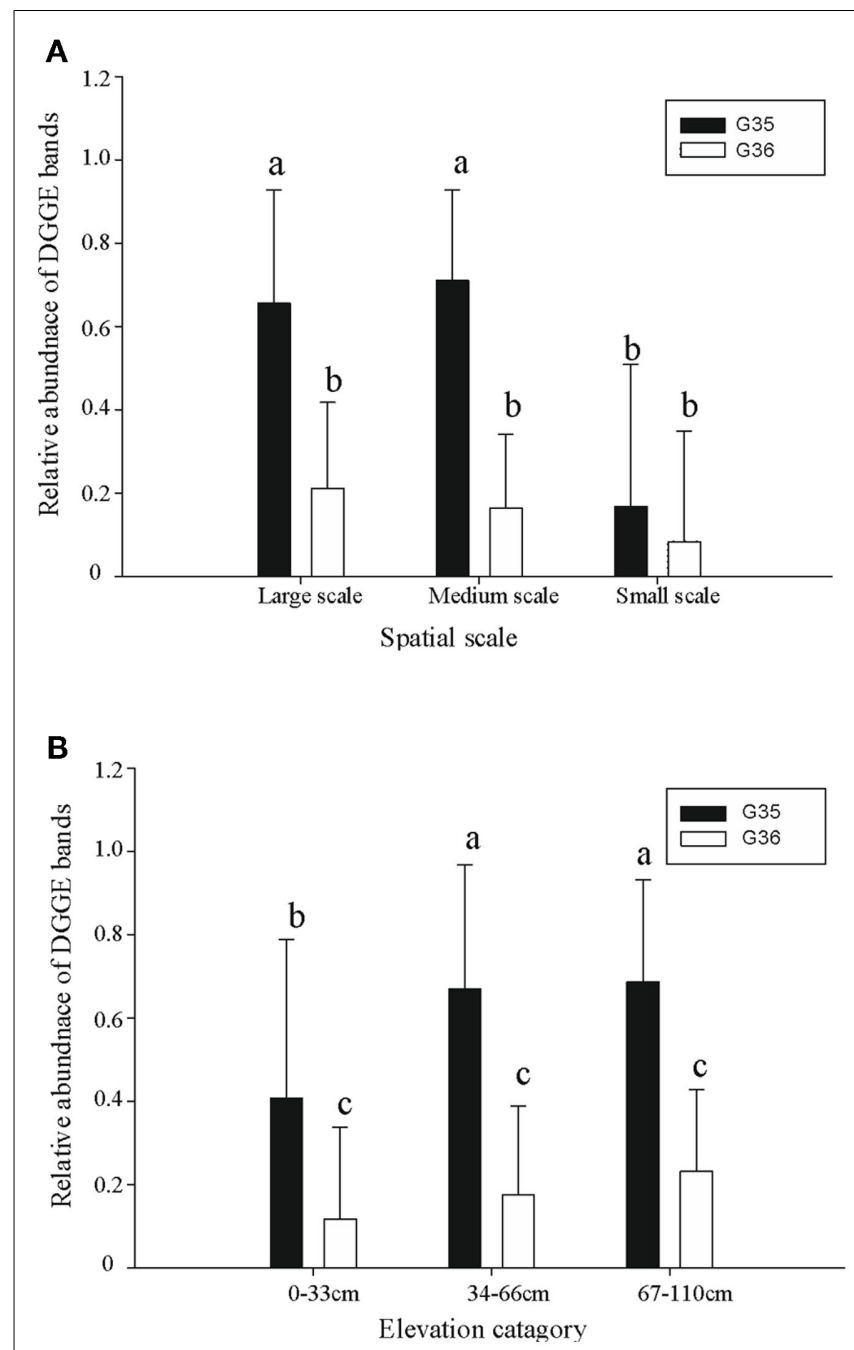

FIGURE 6 |The relative abundance of two dominant Ga-FeOB DGGE bands at different spatial scales $(A)$ and elevation levels (B). Indicated are means $\pm S D$. Different letters indicate significant differences $(p<0.01)$ between bars. For factor "spatial" number of observations is $n=18$ (Large), $n=22$ (Medium), $n=14$ (Small) while for factor "elevation" this is $n=25$ (Large), $n=19$ (Medium), $n=10$ (Small).

development of a cultivation-independent molecular detection assay allows for the reliably revealing of $\mathrm{Ga}-\mathrm{FeOB}$ in environmental settings (Wang et al., 2009; Li et al., 2010) and the ability to relate their distribution to that of other microbes and chemical oxidation processes. The strong correlation we find in this study between the abundance of Ga-FeOB and some of the MOB indicates similar controlling factors, comparable competitive abilities or both. The scarce culture information of FeOB shows that neutrophilic obligate FeOB (Weiss et al., 2007) have similar growth rates as compared to methanotrophs (Dedysh et al., 2007; Belova et al., 2011). However, growth rates under environmental conditions can be quite different from optimal conditions in cultures (Mohanty et al., 2006; Steenbergh et al., 2010) and thus the interactions and competitive abilities of $\mathrm{FeOB}$ and $\mathrm{MOB}$ have to be verified under environmental conditions.
Alternative to the ability to compete with MOB, the dominance of $\mathrm{FeOB}$ over $\mathrm{MOB}$ may also be caused indirectly due to suppression of methanogenesis caused by substrate competition with iron reducers. Hence, sub-optimal methane supply would restrict the activities of MOB. The lag in methanogenic activity as measured in methane production assays on this site in an earlier study points into that direction (Kemnitz et al., 2004). Methane flux measurements executed on the same day as sampling was done in this study yielded values ranging from methane uptake $(24 \mathrm{mg}$ $\mathrm{CH}_{4} \mathrm{~m}^{-1}$ /day) to net emission (180 $\mathrm{mg} \mathrm{CH}_{4} \mathrm{~m}^{-1}$ /day; data not shown). This highly variable emission, with negative values and values even in the range of rice fields does not allow for conclusive statements toward methane availability for MOB. However, earlier studies on this site demonstrated immediate in vitro methane consumption displaying rates in the range of high methane habitats (Steenbergh et al., 2010; Bodelier et al., 2012) suggesting continuous methane availability for MOB. It will require more detailed studies, monitoring soil iron $\left(\mathrm{Fe}^{2+}, \mathrm{Fe}^{3+}\right)$ as well as methane availability in parallel to $\mathrm{FeOB}$ and $\mathrm{MOB}$ community assessments to obtain supporting evidence for "competitive ability" or the "substrate limitation" hypotheses.

In contrast to the distribution based on the measured points only, spatial interpolation maps of Ga-FeOB and MOB abundances reveal that $\mathrm{Ga}-\mathrm{FeOB}$ and type $\mathrm{Ib} \mathrm{MOB}$ display spatial autocorrelation which reflects the underlying hydrological gradient (i.e., combined effects of moisture content and elevation; Figure 7). Type Ia and II MOB displayed a distribution not spatially correlated to the hydrological gradient, with type Ia displaying highest abundances at intermediate moisture and type II showing a patchy distribution over the entire gradient. This differential distribution may be related to the different ecological "strategies" described for the various types of MOB (Steenbergh et al., 2010) with the fast-growing, responsive MOB (i.e., type Ia) abundant where substrates are available and type II occupying patches where survival of periods without substrate is required. A very similar spatial distribution of type II and type Ia MOB was found in a hydrological gradient in a littoral zone of a freshwater lake (Siljanen et al., 2011) supporting niche differentiation of $\mathrm{MOB}$ with respect to hydrology-associated environmental factors. In the study of Siljanen et al., type Ib also displayed a strong spatial autocorrelation with the hydrological gradient, but in contrast to the present study a positive relationship was found with moisture content. This can be explained by the fact that what is assigned as type Ib MOB contains uncultured as well as cultured representatives with quite different characteristics as might be concluded from their original habitats (Lüke et al., 2010; Semrau et al., 2010). Hence, interpreting the similarity between the distribution of type Ib and $\mathrm{Ga}-\mathrm{FeOB}$ in our irregularly flooded riparian site as being groups that have similar ecological characteristics, would be rather speculative. The most likely explanation for the strong cooccurrence is the common dependence on oxic-anoxic interfaces and microaerophilic conditions, which $\mathrm{Ga}-\mathrm{FeOB}$ require to compete successfully with chemical oxidation(Emerson et al., 2010) and to ensure the availability of $\mathrm{O}_{2}, \mathrm{Fe}^{2+}$, and methane. Additional support for common ecological niches comes from the fact that type Ib MOB are abundant members of the MOB community in rice field soils (Lüke et al., 2010; Ho et al., 2011), a habitat 
Table 2 | Spearman rank correlation table of measured environmental parameters and gene copy numbers of Ga-FeOB and type la, lb, and II MOB.

\begin{tabular}{|c|c|c|c|c|c|c|c|}
\hline & Elevation & Moisture (\%) & Organic matter & WFPS & Type la & Type lb & Type II \\
\hline \multicolumn{8}{|l|}{ Elevation } \\
\hline Moisture (\%) & -0.54 & & & & & & \\
\hline WFPS & -0.28 & 0.14 & 0.03 & & & & \\
\hline Type la & 0.24 & -0.38 & -0.16 & -0.33 & & & \\
\hline $\mathrm{FeOB}$ & 0.52 & -0.44 & -0.20 & 0.29 & 0.58 & 0.63 & 0.59 \\
\hline
\end{tabular}

Values in bold are statistically different $(p<0.05)$.

WFPS, water filled pore space.

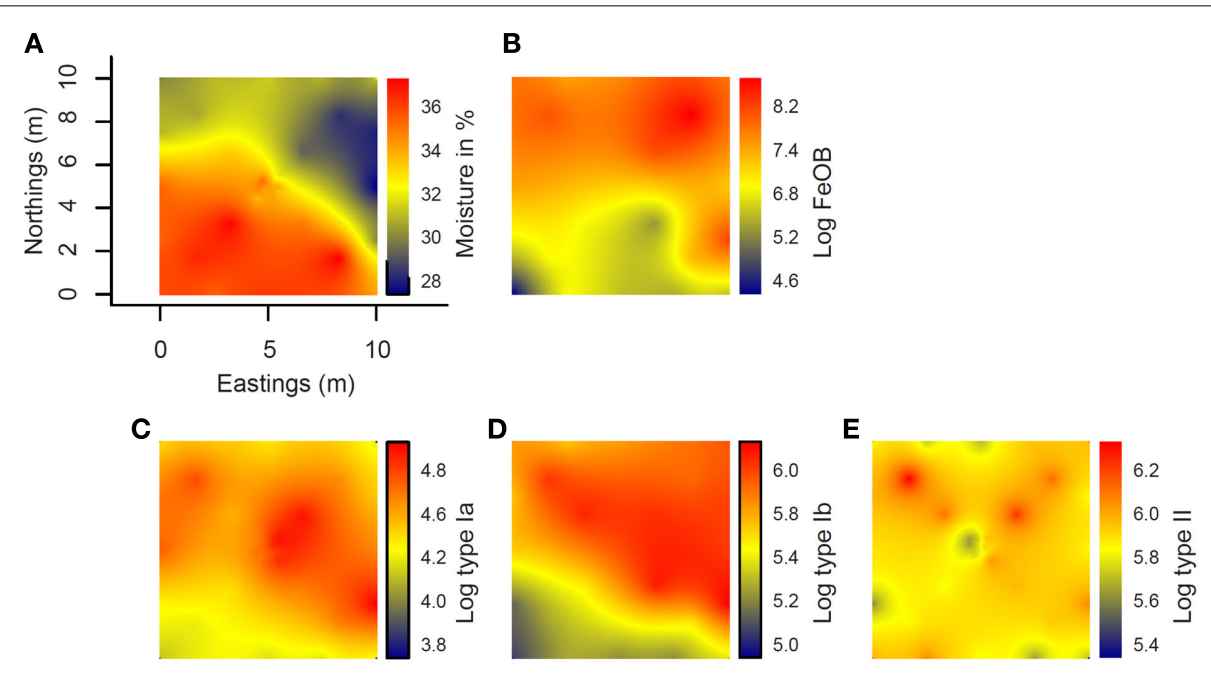

FIGURE 7 | Spatial interpolation maps (kriging maps) of the distribution at the study site of moisture content $(A)$ and log-transformed gene copy number from Ga-FeOB specific qPCR (B), type la (C), type lb (D), and type
II methanotrophs specific qPCRs (E). Color bar to the right of each map indicates extrapolated values of either moisture content or log-transformed gene copy number values.
Table 3 | Parameters for geostatistical analysis of log-transformed qPCR data of $\mathrm{FeOB}$ and MOB taxa and percentage of moisture content.

\begin{tabular}{llllc}
\hline Parameter & Nugget & Sill & $\begin{array}{l}\text { Spatial } \\
\text { dependence }\end{array}$ & $\begin{array}{l}\boldsymbol{p} \text {-Range (m) } \\
\boldsymbol{p}<\mathbf{0 . 0 5}\end{array}$ \\
\hline Moisture & 1.856 & 6.514 & 0.71 & 5.38 \\
FeOB & None & 0.922 & 1.00 & 12.57 \\
Type la & 0.261 & 0.396 & 0.34 & 6.34 \\
Type Ib & 0.047 & 0.179 & 0.74 & 14.78 \\
Type II & 0.148 & 0.218 & 0.32 & 2.07
\end{tabular}

The nugget quantifies the amount of variability at distance of zero, the sill is the value where the variogram levels off, the spatial dependence indicates the proportion of variability of the data that was modeled, the practical range (p-range) equal to the distance at which $95 \%$ of the sill has been reached.

which is very similar to the studied floodplain soil (Conrad et al., 2008).
A striking phenomenon in our study was the clear deviating Ga-FeOB and MOB abundances at the small (i.e., cm) scale. For type $\mathrm{Ia} \mathrm{MOB}$ and the $\mathrm{FeOB}$, gene copies were below detection limit in a large number of samples (Typ Ia 11 out 23, FeOB 17 out 23), but also for type Ib as well as type II the abundances were generally significantly lower. Siljanen et al. (2011) observed much less spatial structure and variance at the $\mathrm{cm}$ scale within a littoral hydrological gradient than at a larger scale. Abundance is obviously affected by small scale differences, disconnected from the large-scale environmental gradient. The only measured variables that deviated in small scale plot are moisture and organic matter contents, which are both significantly higher in the small scale samples. The combination of these factors can put constraints on the availability of oxygen by a more intense competition with heterotrophs (van Bodegom et al., 2001b). Nevertheless, the lack of direct experimental evidence for competitive interactions between heterotrophs, Ga-FeOB, and MOB renders every explanation speculative. Fact is though that the observed local deviations in diversity and abundance of $\mathrm{Ga}-\mathrm{FeOB}$ and $\mathrm{MOB}$ would have 
gone unnoticed in a more coarse sampling design along with the useful ecological information associated to it. Other authors have observed clear spatial patterns in response to agricultural management on meter scales (Philippot et al., 2009a,b; Wessen et al., 2011) using geostatistical approaches. It would be exciting to see whether the generalizations derived from these latter sampling schemes would hold when small scale assessments would have been executed.

Besides the variation between sampling scales there is also large variation in gene abundance over several orders of magnitude between samples from the same sampling scale, even when $\mathrm{cm}$ apart. This holds both true for Ga-FeOB as well as MOB. Hence, the possible solutions for the observed variability should come from factors affecting both groups of microbes. Considering the conflicting aspects of $\mathrm{Fe}$ (III) and methane availability (i.e., competition of methanogens and iron reducers), oxygen would be the most likely factor affecting both the distribution of Ga-FeOB and MOB. The sampled floodplain soil consists of heavy clay which has already limited air penetration that can even be worse when the soil is compacted. The latter has been show to influence methane oxidation in soil (Dalal et al., 2008; Gebert et al., 2011.). In this floodplain this can both be caused by the floodwater itself but also by trampling of the cows which are present in this area for nature management purposes. This would lead to a highly irregular pattern of compacted parts of the soil where possibilities for growth and activity for aerobes are very limited. The higher number of samples below the detection limit in the $20 \mathrm{~cm} \times 20 \mathrm{~cm}$ plot may be simply because due to the size of cores taken, the whole surface area was samples and hence, the chance of hitting these "cold spots" is simply higher as compared to the large- and medium-scale samples.

Hence, heterogeneity of physico-chemical conditions and associated substrate availability may one part of the explanation.

\section{REFERENCES}

Armstrong, W. (1964). Oxygen diffusion from roots of some British bog plants. Nature 204, 801.

Baker, K. L., Langenheder, S., Nicol, G. W., Ricketts, D., Killham, K., Campbell, C. D., and Prosser, J. I. (2009). Environmental and spatial characterisation of bacterial community composition in soil to inform sampling strategies. Soil Biol. Biochem. 41, 2292-2298.

Belova, S. E., Baani, M., Suzina, N. E., Bodelier, P. L. E., Liesack, W., and Dedysh, S. N. (2011). Acetate utilization as a survival strategy of peatinhabiting Methylocystis spp. Environ. Microbiol. Rep. 3, 36-46.

Blothe, M., and Roden, E. E. (2009). Microbial iron redox cycling in a circumneutral-pH groundwater seep. Appl. Environ. Microbiol. 75, 468-473.

Bodelier, P. L. E. (2011). Interactions between nitrogenous fertilizers and methane cycling in wetland and upland soils.
Curr. Opin. Environ. Sustain. 3, 379-388.

Bodelier, P. L. E., Bar-Gilissen, M. J., Meima-Franke, M., and Hordijk, K. (2012). Structural and functional response of methane-consuming microbial communities to different flooding regimes in riparian soils. Ecol. Evol. 2, 106-127.

Bodelier, P. L. E., Frenzel, P., Drake, H. L., Hurek, T., Kusel, K., Lovell, C., Megonigal, P., Reinhold-Hurek, B., and Sorrell, B. (2006). "Ecological aspects of microbes and microbial communities inhabiting the rhizosphere of wetland plants," in Wetlands and Natural Resource Management, eds. J. T. A. Verheven, B. Beltman, R. Bobbink, and D. F. Whigham (Berlin: Springer), 205-238.

Burgin, A. J., Yang, W. H., Hamilton, S. K., and Silver, W. L. (2011). Beyond carbon and nitrogen: how the microbial energy economy couples elemental cycles in diverse ecosystems. Front. Ecol. Environ. 9, 44-52.

The physics of the soil may also influence biological factors like predation by protozoa (Ranjard and Richaume, 2001). The compaction may lead to a heterogenous pattern of soil space inaccessible for protozoa, leading to locally higher numbers of Ga-FeOB and MOB. However, since we have no detailed information on soil-macro and microstructure for the respective samples the explanations offered will remain speculative.

\section{CONCLUSION}

Gallionella-related neutrophilic iron-oxidizing bacteria are abundant throughout the studied riparian floodplain, their distribution reflecting the hydrological gradient. They outnumber various groups of methane oxidizers, demonstrating that FeOB are both able to compete for oxygen with methanotrophs as well as with chemical iron oxidation. The spatial distribution of $\mathrm{Ga}-\mathrm{FeOB}$ resembles the distribution of type $\mathrm{Ib} \mathrm{MOB}$, whereas it deviates from those of type Ia and type II MOB pointing to the fact only one MOB subgroup has similar ecological strategies to Ga-FeOB. Abundances of $\mathrm{Ga}-\mathrm{FeOB}$ as well as $\mathrm{MOB}$ differed significantly from larger scales when sampled on cm scale demonstrating common local limiting factors, which may indicate environmental boundaries for growth of $\mathrm{Ga}-\mathrm{FeOB}$ and MOB.

\section{ACKNOWLEDGMENTS}

The authors would like to thank Foundation "De Ark" for permitting us to take samples at "Ewijkse Waard." This study was part of the ESF-Eurodiversity program (ERAS-CT-2003-98049, 6th EU-framework program) and was financially supported by grants from the Netherlands Organization for Scientific Research (NWO; Grant no. 855.01.108) as by and by the Netherlands Darwin Center for Biogeology (grants 142.16 .1031 and 142.16.1032). This publication is publication nr5218 of the Netherlands Institute of Ecology (NIOO-KNAW).

Chan, C. S., Fakra, S. C., Edwards, D. C., Emerson, D., and Banfield, J. F. (2009). Iron oxyhydroxide mineralization on microbial extracellular polysaccharides. Geochim. Cosmochim. Acta 73, 3807-3818.

Clarke, K. R., and Warwick, R. M. (1998). Quantifying structural redundancy in ecological communities. Oecologia 113, 278-289.

Clarke, K. R., and Warwick, R. M. (2001). A further biodiversity index applicable to species lists: variation in taxonomic distinctness. Mar. Ecol. Prog. Ser. 216, 265-278.

Coci, M., Riechmann, D., Bodelier, P. L. E., Stefani, S., Zwart, G., and Laanbroek, H. J. (2005). Effect of salinity on temporal and spatial dynamics of ammonia-oxidising bacteria from intertidal freshwater sediment. FEMS Microbiol. Ecol. 53 , 359-368.

Conrad, R. (2007). Microbial ecology of methanogens and methanotrophs. Adv. Agron. 96, 1-63.
Conrad, R., Klose, M., Noll, M., Kemnitz, D., and Bodelier, P. L. E. (2008). Soil type links microbial colonization of rice roots to methane emission. Glob. Chang. Biol. 14, 657-669.

Cressie, N. A. C. (1993). Statistics for Spatial Data. New York: John Wiley \& Sons.

Dalal, R. C., Allen, D. E., Livesley, S. J., and Richards, G. (2008) Magnitude and biophysical regulators of methane emission and consumption in the Australian agricultural, forest, and submerged landscapes: a review. Plant Soil 309, 43-76.

Dedysh, S. N., Belova, S. E., Bodelier, P. L. E., Smirnova, K. V., Khmelenina, V. N., Chidthaisong, A., Trotsenko, Y. A., Liesack, W., and Dunfield, P. F. (2007). Methylocystis heyeri sp nov., a novel type II methanotrophic bacterium possessing "signature" fatty acids of type I methanotrophs. Int. J. Syst. Evol. Microbiol. 57, 472-479. 
Doyle, M. O., and Otte, M. L. (1997). Organism-induced accumulation of iron, zinc and arsenic in wetland soils. Environ. Pollut. 96, 1-11.

Emerson, D., Fleming, E. J., and McBeth, J. M. (2010). Iron-oxidizing bacteria: an environmental and genomic perspective. Annu. Rev. Microbiol. 64, 561-583.

Emerson, D., and Moyer, C. (1997). Isolation and characterization of novel iron-oxidizing bacteria that grow at circumneutral pH. Appl. Environ. Microbiol. 63, 4784-4792.

Ettema, C. H., and Wardle, D. A. (2002). Spatial soil ecology. Trends Ecol. Evol. (Amst.) 17, 177-183.

Ferreira, T. O., Otero, X. L., De Souza, V. S., Vidal-Torrado, P., Macias, F., and Firme, L. P. (2010). Spatial patterns of soil attributes and components in a mangrove system in Southeast Brazil (Sao Paulo). J. Soils Sediments 10, 995-1006.

Fleming, E. J., Langdon, A. E., MartinezGarcia, M., Stepanauskas, R., Poulton, N. J., Masland, E. D. P., and Emerson, D. (2011). What's new is old: resolving the Identity of Leptothrix ochracea using single cell genomics, pyrosequencing and FISH. PLoS ONE 6, el7769. doi:10.1371/journal.pone.0017769

Fortin, D., and Langley, S. (2005). Formation and occurrence of biogenic iron-rich minerals. Earth Sci. Rev. 72, 1-19.

Franklin, R. B., and Mills, A. L. (2003). Multi-scale variation in spatial heterogeneity for microbial community structure in an eastern Virginia agricultural field. FEMS Microbiol. Ecol. 44, 335-346.

Gebert, J., Groengroeft, A., and Pfeiffer, E. M. (2011). Relevance of soil physical properties for the microbial oxidation of methane in landfill covers. Soil Biol. Biochem. 43, 1759-1767.

Gutknecht, J. L. M., Goodman, R. M., and Balser, T. C. (2006). Linking soil process and microbial ecology in freshwater wetland ecosystems. Plant Soil 289, 17-34.

Hartman, W. H., Richardson, C. J., Vilgalys, R., and Bruland, G. L. (2008). Environmental and anthropogenic controls over bacterial communities in wetland soils. Proc. Natl. Acad. Sci. U.S.A. 105, 17842-17847.

Ho, A., Lüke, C., and Frenzel, P. (2011). Recovery of methanotrophs from disturbance: population dynamics, evenness and functioning. ISME J. 5, 750-758.

Kemnitz, D., Chin, K. J., Bodelier, P., and Conrad, R. (2004). Community analysis of methanogenic archaea within a riparian flooding gradient. Environ. Microbiol. 6, 449-461.

Kogel-Knabner, I., Amelung, W., Cao, Z. H., Fiedler, S., Frenzel, P., Jahn, R., Kalbitz, K., Kolbl, A., and Schloter, M. (2010). Biogeochemistry of paddy soils. Geoderma 157, $1-14$.

Kolb, S., Knief, C., Stubner, S., and Conrad, R. (2003). Quantitative detection of methanotrophs in soil by novel pmoA-targeted real-time PCR assays. Appl. Environ. Microbiol. 69, 2423-2429.

Laanbroek, H. J. (2010). Methane emission from natural wetlands: interplay between emergent macrophytes and soil microbial processes. A minireview. Ann. Bot. 105, 141-153.

Legendre, P., and Legendre, L. (1998). Numerical Ecology. Amsterdam: Elsevier.

Li, D., Li, Z., Yu, J., Cao, N., Liu, R., and Yang, M. (2010). Characterization of bacterial community structure in a drinking water distribution system during an occurrence of Red Water. Appl. Environ. Microbiol. 76, 7171-7180.

Lovley, D. R. (1997). Microbial Fe(III) reduction in subsurface environments. FEMS Microbiol. Rev. 20, 305-313.

Ludwig, W., Strunk, O., Westram, R., Richter, L., Meier, H., Yadhukumar, Buchner, A., Lai, T., Steppi, S., Jobb, G., Forster, W., Brettske, I., Gerber, S., Ginhart, A. W., Gross, O., Grumann, S., Hermann, S., Jost, R., Konig, A., Liss, T., Lussmann, R., May, M., Nonhoff, B., Reichel, B. Strehlow, R., Stamatakis, A., Stuckmann, N., Vilbig, A., Lenke, M., Ludwig, T., Bode, A., and Schleifer, K. H. (2004). ARB: a software environment for sequence data. Nucleic Acids Res. 32, 1363-1371.

Lüke, C., and Frenzel, P. (2011). Potential of pmoA amplicon pyrosequencing for methanotroph diversity studies. Appl. Environ. Microbiol. 77, 6305-6309.

Lüke, C., Krause, S., Cavigiolo, S., Greppi, D., Lupotto, E., and Frenzel, P. (2010). Biogeography of wetland rice methanotrophs. Environ. Microbiol. 12, 862-872.

Mermillod-Blondin, F., and Lemoine, D. G. (2010). Ecosystem engineering by tubificid worms stimulates macrophyte growth in poorly oxygenated wetland sediments. Funct. Ecol. 24, 444-453.

Mohanty, S. R., Bodelier, P. L. E., Floris, V., and Conrad, R. (2006). Differential effects of nitrogenous fertilizers on methane-consuming microbes in rice field and forest soils. Appl. Env iron. Microbiol. 72, 1346-1354.

Muyzer, G., Dewaal, E. C., and Uitterlinden, A. G. (1993). Profiling of complex microbialpopulations by denaturing gradient gel-electrophoresis analysis of polymerase chain reaction-amplified genes-coding for $16 \mathrm{~s}$ ribosomalRNA. Appl. Environ. Microbiol. 59, 695-700.

Neubauer, S. C., Emerson, D., and Megonigal, J. P. (2002). Life at the energetic edge: kinetics of circumneutral iron oxidation by lithotrophic iron-oxidizing bacteria isolated from the wetland-plant rhizosphere. Appl. Environ. Microbiol. 68, 3988-3995.

Neubauer, S. C., Toledo-Duran, G. E., Emerson, D., and Megonigal, J. P. (2007). Returning to their roots: iron-oxidizing bacteria enhance short-term plaque formation in the wetland-plant rhizosphere. Geomicrobiol. J. 24, 65-73.

Op den Camp, H. J. M., Islam, T. Stott, M. B., Harhangi, H. R., Hynes, A., Schouten, S., Jetten, M. S. M., Birkeland, N. K., Pol, A., and Dunfield, P. F. (2009). Environmental, genomic and taxonomic perspectives on methanotrophic Verrucomicrobia. Environ. Microbiol. Rep. 1, 293-306.

Pan, Y., Bodrossy, L., Frenzel, P., Hestnes, A., Krause, S. B. M., Lüke, C., MeimaFranke, M., Siljanen, H., Svenning, M. M., and Bodelier, P. L. E. (2010). Impacts of inter- and intralaboratory variations on the reproducibility of microbial community analyses. Appl. Environ. Microbiol. 76, 7451-7458.

Philippot, L., Bru, D., Saby, N. P. A., Cuhel, J., Arrouays, D., Simek, M., and Hallin, S. (2009a). Spatial patterns of bacterial taxa in nature reflect ecological traits of deep branches of the 16S rRNA bacterial tree. Environ. Microbiol. 11, 3096-3104.

Philippot, L., Cuhel, J., Saby, N. P. A., Cheneby, D., Chronakova, A., Bru, D., Arrouays, D., Martin-Laurent, F., and Simek, M. (2009b). Mapping field-scale spatial patterns of size and activity of the denitrifier community. Environ. Microbiol. 11 1518-1526.

Ranjard, L., and Richaume, A. S. (2001). Quantitative and qualitative microscale distribution of bacteria in soil. Res. Microbiol. 152, 707-716.

R Development Core Team. (2010). $R: \quad a$ Language and Environment for Statistical Computing. ver. 2.11.1. Available at: http://cran.r-project.org/

Ribeiro, J. R., and Diggle, P. J. (2001). geoR: a package for geostatistical analysis. R. J. 1, 1609-3631.

Ringeval, B., Friedlingstein, P., Koven, C., Ciais, P., De Noblet-Ducoudre, N., Decharme, B., and Cadule, P. (2011). Climate- $\mathrm{CH}_{4}$ feedback from wetlands and its interaction with the climate- $\mathrm{CO}_{2}$ feedback. Biogeosciences 8, 2137-2157.

Schäfer, H., Bernard, L., Courties, C., Lebaron, P., Servais, P., Pukall, R., Stackebrandt, E., Troussellier, M., Guindulain, T., Vives-Rego, J., and Muyzer, G. (2001). Microbial community dynamics in Mediterranean nutrient-enriched seawater mesocosms: changes in the genetic diversity of bacterial populations. FEMS Microbiol. Ecol. 34, 243-253.

Semrau, J. D., Dispirito, A. A., and Yoon, S. (2010). Methanotrophs and copper. FEMS Microbiol. Rev. 34, 496-531.

Siljanen, H. M. P., Saari, A., Krause, S., Lensu, A., Abell, G. C. J., Bodrossy, L., Bodelier, P. L. E., and Martikainen, P. J. (2011). Hydrology is reflected in the functioning and community composition of methanotrophs in the littoral wetland of a boreal lake. FEMS Microbiol. Ecol. 75, 430-445.

Singer, E., Emerson, D., Webb, E. A., Barco, R. A., Kuenen, J. G., Nelson, W. C., Chan, C. S., Comolli, L. R., Ferriera, S., Johnson, J., Heidelberg, J. F., and Edwards, K. J. (2011). Mariprofundus ferrooxydans PV-1 the first genome of a marine $\mathrm{Fe}$ (II) oxidizing Zetaproteobacterium. PLoS ONE 6, e25386. doi:10.1371/journal.pone.0025386

Sobolev, D., and Roden, E. E. (2002). Evidence for rapid microscale bacterial redox cycling of iron in circumneutral environments. Antonie Van Leeuwenhoek 81, 587-597.

Steenbergh, A. K., Meima, M. M., Kamst, M., and Bodelier, P. L E. (2010). Biphasic kinetics of a methanotrophic community is a combination of growth and increased activity per cell. FEMS Microbiol. Ecol. 71, 12-22.

Sundby, B., Vale, C., Caetano, M., and Luther, G. W. (2003). Redox chemistry in the root zone of a salt marsh sediment in the Tagus Estuary, Portugal. Aquat. Geochem. 9, 257-271.

Thauer, R. K., Jungermann, K., and Decker, K. (1977). Energy conservation in chemotrophic anaerobic bacteria. Bacteriol. Rev. 41, 100.

van Bodegom, P., Goudriaan, J., and Leffelaar, P. (2001a). A mechanistic 
model on methane oxidation in a rice rhizosphere. Biogeochemistry 55, 145-177.

van Bodegom, P., Stams, F., Mollema, L., Boeke, S., and Leffelaar, P. (2001b). Methane oxidation and the competition for oxygen in the rice rhizosphere. Appl. Environ. Microbiol. 67, 3586-3597.

Wang, J. J. (2011). Ecology of Neutrophilic Iron-Oxidizing Bacteria in Wetland Soils. Ph.D. thesis, University of Utrecht, Utrecht.

Wang, J. J., Muyzer, G., Bodelier, P. L. E., and Laanbroek, H. J. (2009). Diversity of iron oxidizers in wetland soils revealed by novel $16 \mathrm{~S}$ rRNA primers targeting Gallionella-related bacteria. ISME J. 3, 715-725.

Wang, J. J., Vollrath, S., Behrends, T., Bodelier, P. L. E., Muyzer, G., MeimaFranke, M., Den Oudsten, F., Van
Cappellen, P., and Laanbroek, H. J. (2011). Distribution and diversity of Gallionella -like neutrophilic iron oxidizers in a tidal freshwater marsh. Appl. Environ. Microbiol. 77, 2337-2344.

Weiss, J. V., Emerson, D., Backer, S. M., and Megonigal, J. P. (2003). Enumeration of $\mathrm{Fe}(\mathrm{II})$-oxidizing and $\mathrm{Fe}$ (III)-reducing bacteria in the root zone of wetland plants: implications for a rhizosphere iron cycle. Biogeochemistry 64, 77-96.

Weiss, J. V., Rentz, J. A., Plaia, T., Neubauer, S. C., Merrill-Floyd, M., Lilburn, T., Bradburne, C., Megonigal, J. P., and Emerson, D. (2007). Characterization of neutrophilic $\mathrm{Fe}(\mathrm{II})$-oxidizing bacteria isolated from the rhizosphere of wetland plants and description of Ferritrophicum radicicola gen. nov $\mathrm{sp}$ nov., and Sideroxydans paludicola $\mathrm{sp}$ nov. Geomicrobiol. J. 24, 559-570.

Wessen, E., Soderstrom, M., Stenberg, M., Bru, D., Hellman, M., Welsh, A., Thomsen, F., Klemedtson, L., Philippot, L., and Hallin, S. (2011). Spatial distribution of ammoniaoxidizing bacteria and archaea across a 44-hectare farm related to ecosystem functioning. ISME J. 5 , 1213-1225.

Yeates, C., and Gillings, M. R. (1998). Rapid purification of DNA from soil for molecular biodiversity analysis. Lett. Appl. Microbiol. 27, 49-53.

Conflict of Interest Statement: The authors declare that the research was conducted in the absence of any commercial or financial relationships that could be construed as a potential conflict of interest.
Received: 23 November 2011; accepted: 06 February 2012; published online: 23 February 2012.

Citation: Wang J, Krause S, Muyzer G, Meima-Franke $M$, Laanbroek $H J$ and Bodelier PLE (2012) Spatial patterns of iron- and methane-oxidizing bacterial communities in an irregularly flooded, riparian wetland. Front. Microbio. 3:64. doi: 10.3389/fmicb.2012.00064

This article was submitted to Frontiers in Terrestrial Microbiology, a specialty of Frontiers in Microbiology.

Copyright (C) 2012 Wang, Krause, Muyzer, Meima-Franke, Laanbroek and Bodelier. This is an open-access article distributed under the terms of the Creative Commons Attribution Non Commercial License, which permits noncommercial use, distribution, and reproduction in other forums, provided the original authors and source are credited. 